\title{
PRIMENA SAVREMENE TEHNOLOGIJE U VASPITANJU I OBRAZOVANJU DECE PREDŠKOLSKOG UZRASTA- PRIKAZ REZULTATA ISTRAŽIVANJA IZ RAZLIČITIH ZEMALJA ${ }^{1}$
}

\author{
Anastasija Mamutović², Marija Marković, Zorica Stanisavljević Petrović \\ Univerzitet u Nišu, Filozofski fakultet, Departman za pedagogiju
}

\begin{abstract}
Apstrakt: Primena savremene tehnologije u vaspitno-obrazovnom radu odnosi se na kreiranje adekvatnog pristupa i modela upotrebe produkata tehnologije na svim nivoima sistema vaspitanja i obrazovanja. Informatizacija savremenog društva dovodi do promene obrazovnih standarda, kao i metoda i sredstava koji se primenjuju u vaspitno-obrazovnom radu. Cilj rada jeste da se na osnovu teorijske analize naučne literature utvrdi na koji način se u zemljama sveta savremena tehnologija primenjuje $u$ vaspitno-obrazovnom radu sa decom predškolskog uzrasta i da se predstave rezultati studija koje ukazuju na efekte tehnoloških produkata na razvoj, ponašanje i učenje predškolske dece. Pored analize rezultata u pogledu primene savremene tehnologije u predškolskim ustanovama, analizirani su i rezultati istraživanja koja se odnose na primenu savremene tehnologije u porodičnom kontekst. Uočeno je da je prisutna upotreba savremene tehnologije u radu vaspitača, kao i da kod vaspitača postoji razvijena svest o značaju informatičke edukacije i potrebi stručnog usavršavanja u oblasti primene savremene tehnologije u radu sa decom predškolskog uzrasta. Što se porodičnog konteksta tiče, analiza rezultata istraživanja pokazuje da se u 21 . veku u porodičnom kontekstu koristi širok spektar tehnoloških produkata čiji su verni korisnici i sama deca predškolskog uzrasta.
\end{abstract}

Ključne reči: savremena tehnologija, predškolski uzrast, predškolske ustanove, porodični kontekst

\section{Uvod}

U razvijenim zemljama sveta uvođenje novih medijskih tehnologija je neizostavni deo formalnog obrazovanja, počevši od predškolskog pa sve do

\footnotetext{
${ }^{1}$ Rad je nastao kao rezultat rada na projektu „Unapređenje profesionalnih kompetencija budućih pedagoga u okviru osnovnih akademskih studija pedagogije“ (360/1-16-5-01) koji se sprovodi na Univerzitetu u Nišu - Filozofski fakultet. Ovaj rad je finansijski podržalo Ministarstvo prosvete, nauke i tehnološkog razvoja Republike Srbije.
}

${ }^{2}$ anastasija.mamutovic@filfak.ni.ac.rs 
univerzitetskog nivoa. Na našim prostorima još uvek nije došlo do adekvatnog pozicioniranja savremene tehnologije u procesu vaspitanja i obrazovanja, iako je na nivou osnovnog, srednjeg i visokoškolskog sistema uočljiv veliki napredak. Dakle, može se reći da je najsloženija situacija na nivou predškolskog vaspitanja i obrazovanja, na kojem su prisutni problemi vezani za materijalnu opremljenost predškolskih ustanova i kompetentnost vaspitača (Stanisavljević Petrović i Pavlović, 2017). Iako je poslednjih godina pitanje primene tehnologije u predškolskom vaspitanju i obrazovanju zastupljeno u pedagoškoj literaturi, uglavnom se pomenuta tematika spominje u kontekstu nepostojanja zakonskog okvira koji će omogućiti sistematsku implementaciju.

U cilju prilagođavanja predškolskog vaspitanja i obrazovanja potrebama savremenog društva, potrebno je uzeti u obzir činjenicu da odrastanje dece u 21. veku podrazumeva neprestanu okruženost produktima tehnologije kao što su računari, video igre, obrazovni softveri, internet aplikacije, You tube, iPod, mobilni telefoni i slično. Iz tog razloga se često ističu razlike u načinu razmišljanja starijih generacija i savremenih generacija koje nose epitet „digitalnih urođenika“. Uprkos tome, sistematska implementacija tehnologije u sistem predškolskog vaspitanja i obrazovanja na našim prostorima predstavlja kontroverznu temu (Mikelić Preradović i sar., 2014). Nikulina (Nikulina, 2015) ističe da je informatizacija predškolskog vaspitanja i obrazovanja kompleksan proces koji zahteva angažovanje svih subjekata vaspitno-obrazovnog procesa - vaspitača, roditelja i dece. Ista autorka objašnjava pozitivan uticaj savremene tehnologije činjenicom da istovremeni uticaj zvučnih, grafičkih i audio-vizuelnih informacija poseduje sposobnost da izazove emocionalni naboj kod dece. Na taj način, podstiče se motivacija, aktivno uključivanje dece u proces obrazovanja i intenzivira kognitivna obrada informacija.

Cilj istraživanja jeste da se na osnovu teorijske analize naučne literature utvrdi na koji način se u zemljama sveta savremena tehnologija primenjuje u vaspitnoobrazovnom radu sa decom predškolskog uzrasta $i$ da se predstave rezultati studija koje ukazuju na efekte tehnoloških produkata na razvoj, ponašanje i učenje predškolske dece.

\section{Primena savremene tehnologije u predškolskim ustanovama - pregled rezultata istraživanja iz različitih zemalja}

Primena savremene tehnologije u radu sa decom predškolskog uzrasta postala je u 21. veku uslov modernizacije vaspitno-obrazovnog procesa, a samim tim i profesionalni izazov za vaspitače koji su u predškolskim ustanovama posrednici između dece i produkata tehnologije. Kompetencije vaspitača za primenu savremene tehnologije mogu uticati na način na koji će deca praviti razliku između fiktivnog sveta tehnologije i realnosti, na njihovu procenu pozitivnih i negativnih karakteristika i pravilno razumevanje sadržaja tehnologije (Radetić Paić i Ružić Baf, 2012). Uvođenjem tehnologije čitav proces učenja i usvajanja znanja prenet je u virtuelno okruženje. Uprkos tome, najoptimalniji rezultati u razvoju dece postižu se 
kombinovanjem tradicionalnog i modernog pristupa učenju (Hilčenko \& Jakovljević, 2017).

Svedoci smo života i rada u „digitalnom dobu“, u kojem zemlje širom sveta pokušavaju da iskoriste potencijal savremene tehnologije (Djebbari, 2012; Drigas et al., 2015). Ubrzan tehnološki razvoj uslovio je promenu tradicionalne uloge vrtića. Danas se primena savremene tehnologije u predškolskom dobu smatra važnim elementom procesa obrazovanja i sredstvom koje vaspitačima može pružiti podršku u postizanju vaspitno-obrazovnih ciljeva, a deci ponuditi inovativne vidove sticanja znanja (Chronopoulou \& Riga, 2012; Drigas \& Kokkalia, 2014; Drigas \& Ioannidou, 2013). Podsticanjem dece od strane vaspitača i roditelja da sama donose pravilne odluke o tome kada, na koji način i koliko koristiti produkte tehnologije, razvijaju se zrele ličnosti koje su konstruktori sopstvenog sistema znanja (Thelning \& Lawes, 2001).

Kompetencije vaspitača za primenu savremene tehnologije mogu se definisati kao skup neophodnih znanja i veština potrebnih za integraciju tehnoloških alata u svakodnevnu praksu ustanove. Uspešna implementacija tehnologije u rad predškolske ustanove ne odnosi se samo na učestalu i nametnutu primenu od strane vaspitača, već na odabir odgovarajućeg produkta tehnologije koji će se primeniti u pravo vreme i u skladu sa razvojnim stupnjem dece (Chou, 2013; Suárez-Rodríguez et al., 2012, prema Cruz \& Díaz, 2016).

Nalazi dosadašnjih istraživanja ukazuju da se u predškolskim ustanovama koje su tehnološki opremljene dominantnije koriste određeni produkti savremene tehnologije (Masoumi, 2015). U skladu sa navedenim jesu i rezultati istraživanja koja potvrđuju da vaspitači nisu podjednako kompetentni za primenu svih IKT sredstava (Kamaruddin et al., 2017), kao i na to da su tradicionalna sredstva i dalje dominantnija $\mathrm{u}$ odnosu na produkte savremene tehnologije (Lupu \& Laurenţiu, 2015).

$\mathrm{U}$ pogledu učestalosti upotrebe tehnologije u predškolskim ustanovama korisno je pomenuti rezultate istraživanja koje je sproveo autor Nikolopolou (Nikolopoulou, 2014), a koji ukazuju na to da deca najčešće upotrebljavaju računar za vreme slobodnih aktivnosti u vrtiću, da učestalost upotrebe računara varira od dva do tri puta nedeljno i da je prosečno vreme koje svako dete provede upotrebljavajući računar od 10 do 20 minuta dnevno.

U cilju identifikacije načina na koji se IKT integrišu u vaspitno-obrazovni rad, u tri predškolske ustanove na teritoriji Švedske sprovedeno je istraživanje, koje je polazalo da se u predškolskim ustanovama aplikacija Google maps koristi za predstavljanje domovine dece migranata, You tube kanal za prikazivanje nacionalne odeće i muzike i iPod uređaji za predstavljanje arapske abecede, kako bi deca u ustanovi naučila na koji način pišu njihovi vršnjaci drugih nacionalnosti u zemljama porekla. Stoga, savremena tehnologija može doprineti promovisanju demokratskih vrednosti i pružiti vaspitačima mogućnost da podstaknu motivaciju, saradnju i interakciju dece (Masoumi, 2015).

U etiopskom sistemu predškolskog vaspitanja i obrazovanja koristi se multimedijalni PKLS sistem koji služi kao podrška razvoju dečijih kognitivnih 
veština prepoznavanja, prisećanja, klasifikacije i serijacije. Sistem PKLS podeljen je na tri ključne oblasti učenja: slova engleskog jezika, amarhijska (amharic) slova i delovi ljudskog tela. Kako bi se ispitala efikasnost pomenutog interaktivnog sistema, pristupilo se realizaciji istraživanja u kojem je jedna grupa dece radila na tradicionalan način, dok je druga grupa radila po PKLS sistemu. Procena efikasnosti načina rada izvršena je opservacijom. Tačnije, testirano je trajanje pažnje dece i nivo zainteresovanosti za praćenje predstavljanog sadržaja. U prvom krugu, deca koja su podučavana korišćenjem tradicionalnih materijala za učenje četiri minuta nakon početka eksperimenta počela su razgovarati i ispoljavala su znake umora $i$ nezainteresovanosti.Za razliku od njih, deca koja su radila po modelu multimedijalnog PKLS sistema ostala su fokusirana na učenje predviđenog sadržaja u trajanju od petnaest minuta. Imajući na umu kratkoročnost pažnje dece predškolskog uzrasta, istraživači su u PKLS sistem uključili propratne elemente kao što su tekst, zvuk, video, razne boje i animacije, kako bi pomenuti multimedijalni elementi kognitivno angažovali decu. Rezultati eksperimenta pokazali su da je upotreba multimedijalne aplikacije pozitivno uticala na pažnju dece, unapredila učinak i efikasnost učenja i nivo zadovoljstva dece u radu (Tamirat \& Berhan, 2014).

Slično prethodnom, rezultati istraživanja sprovedenog u gradu Ekiti 2013/14. godine pokazuju da savremena tehnologija može biti veoma efikasno sredstvo u razvoju matematičke pismenosti dece ranog uzrasta. Tačnije, cilj studije jeste bio da se ustanovi da li će deca savladati oblast matematike i prirodnih nauka uspešnije ukoliko se u radu primenjuje savremena tehnologija ili ukoliko se radi na tradicionalan način. Ekperimentalna (132) i kontrolna grupa (128) dece najpre su podvrgnute inicijalnom testiranju. U pre i post testiranja korišćen je EMSAT test koji meri stepen matematičkih kompetencija i namenjen je deci predškolskog uzrasta. Deca u kontrolnoj i eksperimentalnoj grupi savladavala su iste oblasti: matematiku, recikliranje i rastvorljivost materijala u vodi. Međutim, u kontrolnoj grupi vaspitačima i deci nije bio na raspolaganju računar koji je korišćen u eksperimentalnoj grupi svake nedelje. Rezultati post-testa pokazali su znatno veći napredak dece iz eksperimentalne grupe $u$ ispitivanim oblastima učenja (Oluwadare, 2015).

Kada razmatramo primere dobre prakse u pogledu primene savremene tehnologije zanimljivo je pomenuti da su predškolske ustanove na teritoriji Češke tehnološki opremljene i da vaspitači već godinama uspešno koriste u vaspitnoobrazovnom radu program „Kid Smart“. Cilj jeste da se deca u ranom uzrastu upoznaju sa tehnologijom koja će postati neizostavan deo njihovog školovanja u budućnosti. Softverski program je veoma lako koristiti i namenjen je učenju dece osnovama matematike, logike i prirodnih nauka. Pored toga, korišćenje softvera razvija kreativnost i podstiče saradnju dece u predškolskoj ustanovi. Zadatak vaspitača jeste da pre neposredne primene softvera osmisle aktivnosti na računaru, koje su u skladu sa tematskim oblastima programa po kojem se realizuje vaspitnoobrazovni rad. U Češkoj se smatra da je uzrast od četiri godine optimalan period za početak tehnološkog opismenjivanja dece, kao i da se rad deteta na računarima uvek mora obavljati pod nadzorom odrasle osobe koja će izabrati one programe koji 
su najpogodniji za dete, s obzirom na njegove individualne sposobnosti. Takođe se smatra da je veoma važno pratiti i ograničiti vreme koje dete provodi upotrebljavajući tehnologiju, a koje zavisi od uzrasta. Osim toga, smatra se da je veoma važno da se fizičke aktivnosti ne zapostave zbog učestalog korišćenja tehnologije. Rezultati sprovedenog istraživanja ukazuju na pozitivne efekte primene razvijenog programa (Sehnalová, 2014).

Kada se razmatraju teškoće u procesu implementacije savremene tehnologije u vaspitno-obrazovnom radu, na osnovu teorijske analize rezultata istraživanja, može se uočiti da je najčešće reč o nedostatku tehničke podrške, deficitu potrebnih znanja i veština vaspitača (Kamaruddin et al., 2017), neadekvatnim uslovima u instituciji (nedostatak struje i siromaštvo), nedovoljno obučenim vaspitačima koji imaju otpor prema primeni savremene tehnologije (Kaindio \& Wagithunu, 2014), nedovoljnoj opremljenosti predškolskih ustanova produktima tehnologije, nedostatatku stručnjaka koji će vaspitače obučiti da na adekvatan način koriste IKT resurse (Cevher Kalburan et al., 2011) i neadekvatnoj formalnoj i neformalnoj obuci koja se nudi vaspitačima (Liu et al., 2014).

Nasuprot tome, rezultati drugih istraživanja ukazuju na kompetentnost vaspitača za primenu savremene tehnologije. Primera radi, rezultati istraživanja sprovedenog u Češkoj pokazuju da se računar u predškolskoj ustanovi najčešće koristi jednom nedeljno, u zavisnosti od interesovanja dece i vaspitno-obrazovnog programa. Uglavnom se koriste bajke, basne, obrazovni programi i internet izvori koji se pronalaze na specijalnim portalima za decu ranog uzrasta. Dalje, istraživanje sprovedeno u Grčkoj, ukazuje na osposobljenost vaspitača da efikasno upotrebljavaju produkte tehnologije u vaspitno-obrazovnom radu. Tačnije, ispitanici su najpre formulisali scenario digitalne priče, a nakon toga su prikupljali digitalne materijale kao što su slike, animacije, video klipovi, muzika, auditivni i zvučni zapisi, koje su primenili u radu sa decom. Rezultati istraživanja pokazuju da su vaspitači primenom digitalnog pripovedanja podstakli učenje, kreativnost i jezički razvoj dece (Toki \& Pange, 2014). U pogledu polnih razlika, rezultati istraživanja koje je sproveo autor Adodo (Adodo, 2012) pokazuju da vaspitači muškog pola pozitivnije procenjuju sopstvene kompetencije za primenu savremene tehnologije, u odnosu na vaspitačice.

Važno je napomenuti da, uprkos nedostatku tehnoloških kompetencija i nedovoljnoj opremljenosti ustanova, nalazi brojnih istraživanja ukazuju na pozitivne stavove vaspitača prema primeni savremene tehnologije. Najčešće navođeni pozitivni efekti i prednosti korišćenja tehnologije, od strane vaspitača koji su činili uzorak istraživanja, jesu pripremljenost za polazak u školu, sticanje operativnih veština, proširivanje znanja, razumevanje sveta, razvijanje dispozicija za učenje, podsticanje kognitivnog razvoja i matematičkih sposobnosti, koordinacija očiju i ruku, podsticanje verbalnih sposobnosti i motivacije, razvoj sposobnosti čitanja i pisanja, ostvarivanje ciljeva učenja i obezbeđivanje zabave i razonode dece (CevherKalburan et al., 2011; Konca et al., 2015; Liu et al., 2014; Nikolopoulou, 2014; Plowman et al., 2012; Sehnalová, 2014).

Međutim, prisutna je i na upoznatost vaspitača sa potencijalnim negativnim efektima primene savremene tehnologije u radu sa decom predškolskog uzrasta 
poput manjka fizičke aktivnosti, zdravstvenih problema, teškoća u komunikaciji, ograničavanja mašte, fantazije i proširivanja vokabulara dece, nerazlikovanja fikcije od stvarnosti, zavisnosti i sl. (Sehnalová, 2014).

Ustanovljeno je da je vaspitačima najpre potrebno obezbediti adekvatnu obuku u oblasti primene tehnologije, a nakon toga im omogućiti da stečena znanja primene u radu sa decom (Bourbour et al., 2015; Oluwadare, 2015). Primera radi, u Hong Kongu se od vaspitača očekuje da se formalno obučavaju u IT oblasti kako bi efikasno integrisali tehnologiju u vaspitno-obrazovni rad. Takođe se polazi od činjenice da direktori imaju presudnu ulogu u procesu uspešne modernizacije prakse vaspitno-obrazovnog rada. Tačnije, od njih se očekuje da inspirišu i i ohrabre vaspitače da se suoče sa izazovima koji se potencijalno mogu javiti u procesu primene savremene tehnologije. Direktori ustanova moraju zaposlenima biti uzor kada je u pitanju stručno usavršavanje, a isto tako im moraju pružiti i pomoć materijalne, tehničke i personalne prirode. Rezultati jednog istraživanja (Han, 2002) pokazali su da direktori kao načine podsticanja zaposlenih za upotrebu tehnologije u radu koriste ohrabrivanje zaposlenih da pohađaju seminare, obuke i radionice kako bi se tehnološki opismenili, a neke od njih sponzoriše ustanova. Da bi podstakao korišćenje računara u ustanovi, direktor angažuje koordinatora za IT aktivnosti, poziva stručnjake koji će pružiti obuku zaposlenom kadru i od svih vaspitača očekuje da pohađaju najmanje 48 časova obuke. Obuka se organizuje tokom vikenda, a na sopstvenu inicijativu vaspitači mogu naknadno pohađati i druge kurseve.

Istraživanje koje je sprovedeno na uzorku od 157 studenata odseka za predškolsko obrazovanje u Grčkoj pokazalo je da iskustvo obuke u oblasti primene tehnologije doprinosi opadanju skeptizima i rezervisanosti ispitanika prema upotrebi tehnologije i formiranju pozitivnih stavova kod njih (Vitoulis, 2017).

Činjenica da je vaspitačima u procesu primene savremene tehnologije potrebna pomoć stručnjaka iz IT oblasti potvrđena je rezultatima istraživanja sprovedenog u Engleskoj, 2011/12. godine. Rezultati istraživanja pokazali su da je angažovanje stručnjaka u ustanovi pozitivno uticalo na samopouzdanje i spremnost vaspitača da u praksi primenjuju na kreativan način IKT. Zajedničko kreiranje mini filmova nastalo je kao rezultat zadovoljstva vaspitača sopstvenim kompetencijama i motivacije dece da rade na inovativan način (Roberts Holmes, 2014).

Suprotno navedenom, rezultati istraživanja pokazuju da je u Grčkoj i Kini, uprkos održavanju obuka koje podržava vlada, njihova efikasnost procenjena relativno nisko. Bez obzira na činjenicu da se u pomenutim zemljama predškolske ustanove tehnički opremaju i da vaspitači imaju pozitivan stav prema primeni tehnologije, primetne su teškoće u nastojanjima da se tehnologija implementira u vaspitno-obrazovni rad, kao što su neadekvatna formalna i neformalna obuka (Liu et al., 2014).

Važno je napomenuti da analiza rezultata istraživanja pokazuje da uvođenje kurseva $u$ kurikulum studija koje se odnose na primenu tehnologije doprinosi razvoju kompetencija vaspitno-obrazovnog kadra predškolske ustanove. Rezultati istraživanja sprovedenog u Ukrajini pokazali su da je, nakon izučavanja predmeta, „Nove informacione tehnologije u predškolskom obrazovanju“ i „Računarske 
tehnologije u radu sa decom" došlo do značajnih promena u pogledu stepena kompetentnosti budućih vaspitača za primenu tehnologije (Racu et al., 2017).

Sa druge strane, rezultati istraživanja pokazuju i da uvođenje predmeta iz IT oblasti u kurikulume ne mora nužno voditi poboljšanju tehnoloških kompetencija vaspitača. Na primer, u Turskoj se u toku procesa studiranja realizuju dva predmeta, „Computer" i „ITMD“. Kako bi se ispitala njihova efikasnost, pristupilo se sprovođenju istraživanja. Rezultati su pokazali da ispitanici smatraju procenjivane predmete efikasnim, ali smatraju i da se oni moraju modifikovati, kako bi bili korisniji za vaspitno-obrazovni rad. Tačnije, vaspitači su istakli da je sa IT obukom potrebno početi već u prvoj godini studija, da je potrebno predavanja realizovati u računarskim, a ne u klasičnim učionicama, da je potrebno savladavati upotrebu onih aplikacija koje se mogu primenjivati u vaspitno-obrazovnom radu i da je obuku potrebno povezati sa kurikulumom ustanove (Goktas et al., 2008).

\section{Korišćenje IKT u porodičnom kontekstu predškolske dece - prikaz rezultata istraživanja iz različitih zemalja}

Uprkos činjenici da primena savremene tehnologije može imati brojne prednosti u vaspitno-obrazovnom radu sa decom predškolskog uzrasta, neosporno je i da nekontrolisana upotreba uslovljava širok raspon potencijalnih negativnih efekata. Iz tog razloga, neophodno je preventivno informisati roditelje i vaspitače o adekvatnim načinima primene tehnologije koji će biti u službi podsticanja razvoja dece predškolskog uzrasta (Kienig, 2017).

Analiza rezultata istraživanja potvrđuje da deca predškolskog uzrasta u porodičnom kontekstu koriste širok spektar tehnoloških produkata kao što su televizori, mobilni telefoni, računari, CD i DVD plejeri, digitalne kamere, štampači, iPod uređaji, programirane igračke i slično (Genc, 2014; Lepičnik \& Samec, 2013; Li \& Atkins, 2004; Natsiopoulou \& Bletsou, 2011; Nikolopoulou et al., 2010; Rideout et al., 2003: 17; Sălceanu, 2014). Dakle, može se uočiti da se broj korisnika savremene tehnologije u populaciji dece predškolskog uzrasta neprestano povećava (Australia Bureau of Statistics, 2009, prema Natsiopoulou et al., 2013). Nažalost, rezultati istraživanja koje je sproveo autor Genc (Genc, 2014) pokazuju da se tehnologija češće koristi za zabavu i igru nego li za učenje dece, da roditelji retko čitaju knjige svojoj deci i da koriste aplikacije na pametnim telefonima kako bi privukli pažnju dece, disciplinovali ih ili nagradili.

Kada se razmatra učestalost upotrebe savremene tehnologije u porodičnom okruženju, može se uočiti da deca predškolskog uzrasta radnim danima provode od jednog do dva časa dnevno gledajući televiziju, DVD ili video snimke i pola sata upotrebljavajući računar. Vikendom se vremenski interval upotrebe povećava na čak i do tri-četiri sata dnevno (Genc, 2014; Sălceanu, 2014). Zanimljivo je pomenti da je ustanovljeno da socioekonomski status roditelja ne utiče značajno na učestalost upotrebe tehnologije (Linebarger \& Chernin, 2003). Tačnije, kada porodica poseduje računar u domu, deca različitog socioekonomskog statusa ga koriste vremenski gotovo istovetno. 
Kada je reč o nadzoru dece prilikom upotrebe računara, rezultati istraživanja sprovedenog u Rumuniji, pokazali su da $35.17 \%$ roditelja sa decom uspostavlja pravila vezana za upotrebu računara, $34.34 \%$ roditelja nameće deci rigorozna pravila u pogledu upotrebe i $30.47 \%$ dece može pristupiti računaru kada god to poželi. Takođe, istraživanjem je ustanovljeno da $42.87 \%$ roditelja nadgleda aktivnosti dece na računaru kada ima slobodnog vremena, $24.25 \%$ dosledno nadgleda dečije aktivnosti, $18.85 \%$ roditelja se uključuje u aktivnosti dece na računaru kako bi pružili pomoć i podršku, $8.64 \%$ roditelja veruje da deca poštuju ustanovljena pravila upotrebe i 5.39\% roditelja nadgleda decu samo onda kada koriste internet na računaru (Sălceanu, 2014).

Slično tome, rezultati istraživanja koje je sprovedeno u Grčkoj pokazuju da deca predškolskog uzrasta bez odobrenja i nadzora svojih roditelja samostalno uključuju i koriste TV (62.4\%) i računar (62.8\%). Takođe, u istraživanju je uočena povezanost između uzrasta dece i aktivnosti igranja na računaru - deca starijeg predškolskog uzrasta su najčešće koristila računar samostalno, za razliku od dece mlađeg predškolskog uzrasta koja računar koriste u saradnji sa roditeljima (Natsiopoulou \& Bletsou, 2011).

$\mathrm{U}$ pogledu strategija koje roditelji koriste za ograničavanje upotrebe tehnologije, rezultati istraživanja sprovedenog u Sloveniji pokazuju da je reč o postavljanju uređaja koje deca ne koriste učestalo na visoke police ili u sobe koje se zaključavaju i skrivanju tehnoloških uređaja. Razlozi zbog kojih se deci ograničava pristup određenim produktima tehnologije jesu komplikovana upotreba, pristup neprimerenim sadržajima, oštećenje uređaja, potencijalni negativni efekti i štetnost upotrebe tehnologije za decu ranog uzrasta (Lepičnik \& Samec, 2013).

Posmatrano sa aspekta polnih razlika, rezultati istraživanja sprovedenog u Turskoj pokazuju da roditelji učestalije pružaju sugestije pri upotrebi tehnologije deci ženskog pola. Osim toga, uočeno je da majke učestalije od očeva usmeravaju decu prilikom upotrebe tehnoloških produkata, da imaju kritičnije stavove pri proceni potencijalnih negativnih efekata primene tehnologije (Ekici, 2016), kao i da dominantnije nadgledaju decu prilikom upotrebe računara (Sălceanu, 2014). U skladu sa navedenim su i rezultati istraživanja sprovedenog u Atini 2009. godine, koji potvrđuju da se pristup tehnologiji u većoj meri ograničava devojčicama nego dečacima (Nikolopoulou et al., 2010). Za razliku od uverenja da su devojčice nezainteresovane za upotrebu tehnologije, rezultati istraživanja koje su sproveli Lajnbarger i Černin (Linebarger \& Chernin, 2003) ukazuju na veći afinitet i sklonost devojčica ka upotrebi računara, u odnosu na dečake. Rezultati istraživanja su takođe pokazali da devojčice češće povezuju pozitivne emocije i osobine sa upotrebom računara.

Rezultati istraživanja pokazuju da roditelji sa višim stepenom obrazovanja pozitivnije procenjuju uticaj tehnologije na različite oblasti dečijeg razvoja, u odnosu na roditelje sa nižim stepenom obrazovanja. Osim toga, roditelji smatraju da primena savremene tehnologije u ranom uzrastu razvija motoričke, komunikacijske, socijalne, kulturne i kompetencije za učenje, kao i da doprinosi sticanju veština i znanja koje mogu koristiti detetu u daljem školovanju. Pored navedenog, pokazalo 
se da su roditelji upoznati i sa negativnim efektima primene savremene tehnologije kao što su pristup sadržajima koji promovišu nasilje, ugrožavanje fizičkog zdravlja, pogoršanje vida, gojaznost, gubitak kontakta sa realnošću, zavisnost i asocijalnost (Lepičnik \& Samec, 2013).

$\mathrm{U}$ pogledu uticaja socioekonomskog statusa na stavove o upotrebi tehnologije, rezultati istraživanja sprovedenog u Grčkoj pokazuju da ispitanici višeg socioekonomskog statusa pozitivnije procenjuju uticaj primene IKT na usvajanje znanja, razvoj matematičkih i lingvističkih veština, podsticanje mašte i kreativnosti dece, u odnosu na roditelje nižeg socioekonomskog statusa. Rezultati studije pokazuju i da kategorija roditelja višeg materijalnog statusa ne smatra da primena računara potiskuje ulogu vaspitača i njegovu komunikaciju sa decom u ustanovi. Pored toga, istraživanjem je ustanovljeno da roditelji imaju pozitivan stav prema integraciji tehnologije u vaspitno-obrazovni rad predškolske ustanove, kao i da smatraju da računari podstiču zabavu, razonodu i aktivno učešće u procesu učenja (Natsiopoulou et al., 2013). Do gotovo istih podataka došli su i autori Lajnbarger i Černin (Linebarger \& Chernin, 2003) prilikom sprovođenja istraživanja na teritoriji Kanzasa. Naime, rezultati pomenutog istraživanja pokazali su da roditelji nižeg socioekonomskog statusa, za razliku od roditelja koji pripadaju radničkoj i srednjoj klasi, ne smatraju internet i računar korisnim obrazovnim alatima. Sa druge strane, deca pomenute kategorije roditelja se češće od dece roditelja višeg socioekonomskog statusa opredeljuju za upotrebu računara kada žele da nauče nešto novo.

Slično prethodno navedenom, rezultati istraživanja koje je sprovedeno u Rumuniji ukazuju na upoznatost roditelja sa prednostima i nedostacima upotrebe tehnologije. Preciznije, prednosti računarskih igara koje su roditelji najčešće navodili jesu: razvoj mišljenja, kreativnosti, spretnosti, takmičarskog duha, učenje stranih jezika, poboljšanje memorije i pamćenja, razvoj logičkog razmišljanja, sposobnosti čitanja i pisanja, veština računanja, razvoj ambicije, samopouzdanja, samokontrole, nezavisnosti, društvenosti, timskog duha, odgovornosti i slično. Nasuprot tome, nedostaci upotrebe koje su roditelji navodili jesu: nedostatak fizičkog kretanja, poremećaj vida, bol u kičmi, zavisnost, umor, sukobi braće i sestara prilikom upotrebe, nervoza, asocijalnost, nasilno ponašanje, nesposobnost razlikovanja stvarnosti i fiktivnog sveta, gubljenje vremena i lenjost dece (Sălceanu, 2014).

Prema nalazima istraživanja sprovedenog u Škotskoj može se zaključiti da su roditelji upoznati sa značajem sticanja tehnoloških veština, naročito u starijem predškolskom dobu. Međutim, ispitani roditelji su takođe bili skeptični u proceni važnosti poznavanja tehnologije u ranom dobu. Tačnije, oni su često isticali da su druge aktivnosti prikladnije ovom uzrastu i da je veoma važno da deca ne zanemare igru i druženje zbog učestalog korišćenja tehnologije (Plowman et al., 2012).

Autor Ploumen (Plowman et al., 2012) ističe da se sticanje veština upotrebe tehnologije $u$ porodičnom okruženju najčešće odvija neposredno: razgovorom mobilnim telefonom sa rođacima, snimanjem i štampanjem digitalnih fotografija kućnih ljubimaca, gledanjem porodičnih video snimaka, korišćenjem starih računara i telefona kao rekvizita za igru i slično. 


\section{Zaključak}

Kada sumiramo prethodno navedene rezultate istraživanja uočava se da su tradicionalna sredstva i dalje zastupljenija u vaspitno-obrazovnom radu predškolskih ustanova u odnosu na produkte savremene tehnologije. Takođe je uočeno da problem u nastojanjima da vaspitno-obrazovni proces inovira upotrebom savremene tehnologije predstavljaju nepovoljni uslovi u instituciji i neadekvatna obuka koja se nudi vaspitačima. Dakle, kao što je već istaknuto, iskustvo stručnog usavršavanja $\mathrm{u}$ oblasti primene tehnologije doprinosi kompetentnosti vaspitača i eleminisanju straha i konzervativnih stavova koji se javljaju usled susreta sa nepoznatim načinom rada. Pored toga, uočena je i efikasnost pravovremenog tehnološkog opismenjavanja vaspitača još u toku samih studija, putem predmeta i disciplina iz IT oblasti. Važno je napomenuti i da teorijska analiza rezultata istraživanja ukazuje na upoznatost vaspitača i roditelja sa prednostima i nedostacima upotrebe savremene tehnologije, kao i efektima tehnoloških produkata na razvoj, ponašanje i učenje dece. Rezultati prikazanih istraživanja mogu poslužiti kao važan orijentir za planiranje primene savremenih tehnologija u sistemu predškolskog vaspitanja i obrazovanja kod nas.

Takođe, analiza rezultata istraživanja pokazuje da se u 21 . veku u porodičnom kontekstu koristi širok spektar tehnoloških produkata čiji su verni korisnici i sama deca predškolskog uzrasta. Iz tog razloga roditelji neretko pribegavaju uspostavljanju porodičnih pravila, kao i nadzoru, nadgledanju i kontrolisanju dece prilikom upotrebe IKT.

\section{Literatura}

Adodo, S. O. (2012). A Predictive Study of Pre-Service Teachers' Gender, Self-Concept, Interest and Attitude Towards Interactive Computer Technology (ICTS) in Nigeria Universities Faculties of Education. Journal of Educational and Social Research, 2(3), 145-150.

Bourbour, M., Vigmo, S. \& Samuelsson, I. P. (2015). Integration of interactive whiteboard in Swedish preschool practices. Early Child Development and Care, 185(1), 100 120 .

Cevher Kalburan, N., Yurt, Ö. \& Ömeroğlu, E. (2011). The use of interactive CD-ROM in early childhood education: Teachers' thoughts and practices. Procedia Computer Science, 3, 1555-1561.

Chou, M. J. (2013). Kindergarten teachers' information technology teaching beliefs: The critical path toward teaching effectiveness. Procedia-Social and Behavioral Sciences, 89, 261-269.

Chronopoulou, E. \& Riga, V. (2012). The contribution of music and movement activities to creative thinking in pre-school children. Creative Education, 3(02), 196.

Cruz, F. J. F. \& Díaz, M. J. F. (2016). Generation z's teachers and their digital skills. Comunicar: Revista Científica de Comunicación y Educación, 24(46), 97-105. 
Djebbari, Z. (2012). Effective Teaching with Information Technologies: Towards an Interactive Pedagogy. Journal of Educational and Social Research, 2(3), 141-144.

Drigas, A. \& Kokkalia, G. (2014). ICTs in kindergarten. International Journal of Emerging Technologies in Learning (iJET), 9(2), 52-58.

Drigas, A. S. \& Ioannidou, R. E. (2013). ICT in Special Education: A Review. In: M. D. Lytras et al. (ed.). Communications in Computer and Information Science (357-364). Springer-Verlag Berlin Heidelberg. Retrived from: https://www.researchgate.net/ profile/Athanasios_Drigas/publication/255800111_ICTs_in_Special_Education_A_ Review/links/0c960529b3a93e66fd000000.pdf

Drigas, A., Kokkalia, G. \& Lytras, M. D. (2015). Mobile and Multimedia Learning in Preschool Education. J. Mobile Multimedia, 11(1/2), 119-133.

Ekici, F. Y. (2016). Parents' Views on the Use of Technology in the Early Childhood Period. Journal of Education and Training Studies, 4(12), 58-70.

Genc, Z. (2014). Parents' perceptions about the mobile technology use of preschool aged children. Procedia-Social and Behavioral Sciences, 146, 55-60.

Goktas, Y., Yildirim, Z. \& Yildirim, S. (2008). A review of ICT related courses in preservice teacher education programs. Asia Pacific Education Review, 9(2), 168-179.

Han, C. (2002). Leadership roles of a pre-school principal in the use of information and communication technology: a Hong Kong experience. Contemporary issues in Early childhood, 3(2), 293-297.

Hilčenko, S. \& Jakovljević, N. (2017). Interactive-Multimedia Playful Game Sheets and Panels for Preschool Institutes. Edukacja - Technika - Informatyka, 1(19), 228-234.

Kaindio, M. P. \& Wagithunu, M. N. (2014). Integrating information communication technology skills in preschool education in Kenya. Mediterranean Journal of Social Sciences, 5(5), 89-104.

Kamaruddin, K., Abdullah, C. A. C., Idris, M. N. \& Nawi, M. N. M. (2017). Teachers' level of ICT integration in teaching and learning: A survey in Malaysian private preschool. In: A. Waldron (ed.). AIP Conference Proceedings, 1891/1, (0200751 - 020075-5). AIP Publishing. Retrived from: https:/aip.scitation.org/doi/ pdf $/ 10.1063 / 1.5005408$ ? class $=$ pdf

Kienig, A. (2017). Modern Technology as the New Context of Child Development: Opportunities and Threats. Rocznik Teologii Katolickiej, 16(2), 161-176.

Konca, A. S., Ozel, E. \& Zelyurt, H. (2015). Attitudes of preschool teachers towards using information and communication technologies (ICT). International Journal of Research in Education and Science, 2(1), 10-15.

Lepičnik, J. \& Samec, P. (2013). Communication Technology in the Home Environment of Four-year-old Children (Slovenia). Comunicar, 20(40).

Li, X. \& Atkins, M. S. (2004). Early childhood computer experience and cognitive and motor development. Pediatrics-English Edition, 113(6), 1715-1722. Retrived from: http://citeseerx.ist.psu.edu/viewdoc/download?doi=10.1.1.575.7121\&rep=rep1\&typ $\mathrm{e}=\mathrm{pdf}$

Linebarger, D. L. \& Chernin, A. R. (2003). Young Children, Parents, Computers. IT \& SOCIETY, 1(4), 87-106. 
Liu, X., Toki, E. I. \& Pange, J. (2014). The use of ICT in preschool education in Greece and China: A comparative study. Procedia-Social and Behavioral Sciences, 112, 1167-1176.

Lupu, D. \& Laurenţiu, A. R. (2015). Using new communication and information technologies in preschool education. Procedia-Social and Behavioral Sciences, 187, 206-210.

Masoumi, D. (2015). Preschool teachers' use of ICTs: Towards a typology of practice. Contemporary Issues in Early Childhood, 16(1), 5-17.

Mikelić Preradović, N., Unić, D. \& Boras, D. (2014). Preschool and Primary School Children as Multimedia Learners. International journal of education and information technologies, 8, 171-178.

Natsiopoulou, T. \& Bletsou, M. (2011). Greek preschoolers' use of electronic media and their preferences for media or books. International Journal of Caring Sciences, 4(2), 97-104.

Natsiopoulou, T., Melissa Halikiopoulou, C. \& Lioliou, C. (2013). Effects of family socioeconomic status on parents' views concerning the integration of computers into preschool classrooms. International Journal of Caring Sciences, 6(1), 98.

Nikolopoulou, K. (2014). ICT integration in preschool classes: Examples of practices in greece. Creative Education, 5(6), 402-410.

Nikolopoulou, K., Gialamas, V. \& Batsouta, M. (2010). Young children's access to and use of ICT at home. Review of Science, Mathematics and ICT Education, 4(1), 2540. Retrived from: http://societyandtheory.lis.upatras.gr/index.php/review/article/ view/133

Nikulina, T. V. (2015). Integration of information and communication technologies into preschool education. In: S. Petrovska (ed.). Education in XXI century-conditions and perspectives (228-237). Štip: Univerzitet Goce Delčev. Retrived from:http://js.ugd. edu.mk/index.php/AMC/article/view/1456/1278

Oluwadare, F. A. (2015). ICT Use in Preschool Science Education: A Case Study of Some Private Nursery Schools in Ekiti State. Journal of Education and Practice, 6(31), $75-79$.

Plowman L., McPake, J. \& Stephen C. (2012) Extending opportunities for learning: the role of digital media in early education. In: S. Suggate \& E. Reese (eds.). Contemporary Debates in Child Development and Education, (95-104). Routledge: Abingdon.

Racu, I. I., Lystopad, O. A. \& Mardarova, I. K. (2017). The Formation of Future Preschool Teachers' Competence Required for Using Computer Technology. Science and Education, 5, 24-27.

Radetić Paić, M. \& Ružić Baf, M. (2012). Use of ICT and Inappropriate Effects of Computer Use - Future Perspectives of Preschool and Primary School Teachers. Psychology of Language and Communication, 16(1), 29-38. Retrived from:https://www.degruyter. com/downloadpdf/j/plc.2012.16.issue-1/v10057-012-0003-y/v10057-012-0003-y. pdf

Rideout, V. J., Vandewater, E. A. \& Wartella, E. A. (2003). Zero to six: Electronic media in the lives of infants, toddlers and preschoolers. Retrived from:https://files.eric.ed.gov/ fulltext/ED482302.pdf 
Roberts Holmes, G. (2014). Playful and creative ICT pedagogical framing: a nursery school case study. Early child development and care, 184(1), 1-14.

Sălceanu, C. (2014). The Influence of Computer Games on Children's Development. Exploratory Study on the Attitudes of Parents. Procedia-Social and Behavioral Sciences, 149, 837-841.

Sehnalová, V. (2014). Using ICT in education of preschool children. Journal of Technology and Information Education, 6(1), 4.

Stanisavljević Petrović, Z. i Pavlović, D. (2017). Novi mediji u ranom obrazovanju. Niš: Filozofski fakultet.

Tamirat, M. \& Berhan, G. (2014). Multimedia Application to Improve the Cognitive Skills of Preschool and Kindergarten Children. HiLCoE Journal of Computer Science and Technology, 2(2), 52-57.

Thelning, K. \& Lawes, H. (2001). Information and Communication Technologies (ICT) in the Early Years. Retrived from: http://citeseerx.ist.psu.edu/viewdoc/download?doi= 10.1.1.116.7891\&rep=rep1\&type $=$ pdf

Toki, E. I. \& Pange, J.(2014). ICT use in early childhood education: Storytelling. Tiltai, 66(1), $183-192$.

Vitoulis, M. (2017). The formation of pre-service early childhood educators'perceptions about ict use in early childhood education after an experiential approach. European Journal of Education Studies, 3(5), 22-37.

\title{
THE APPLICATION OF ICT TECHNOLOGY IN EDUCATION OF PRESCHOOL CHILDREN - REVIEW OF RESEARCH RESULTS FROM DIFFERENT COUNTRIES
}

\author{
Anastasija Mamutović, Marija Marković, Zorica Stanisavljević Petrović \\ University of Niš, Faculty of Philosophy, \\ Department of Pedagogy
}

\begin{abstract}
The application of modern technology in educational work refers to the creation of an adequate approach and model of use of technology products at all levels of the education system. Informatization of modern society leads to a change in educational standards, as well as methods and tools used in educational work. The aim of this paper is to determine, on the basis of theoretical analysis of scientific literature, in which countries in the world ICT technology is applied in educational work with preschool children, as well as to present the results of studies that indicate the effects of technological products on the development, behavior and learning of preschool children. In addition to the analysis of the results regarding the application of modern technology in preschool institutions, the results of research related to the application of ICT technology in the family context were also analyzed. It was noticed that the use of ICT technology is present in the work of educators, as well as that educators have
\end{abstract}


a developed awareness of the importance of information education and the need for professional development in the field of ICT technology in working with preschool children. As far as the family context is concerned, the analysis of the research results shows that in the 21 st century, a wide range of technological products are used in the family context, of which preschool children themselves are faithful users.

Keywords: ICT technology, preschool period, preschool institutions, family context.

Citiranje članaka: Mamutović, A., Marković, M. i Stanisavljević Petrović Z. (2020). Primena savremene tehnologije u vaspitanju i obrazovanju dece predškolskog uzrasta - prikaz rezultata istraživanja iz različitih zemalja. Godišnjak za pedagogiju, 5(1), 59-72. 